\title{
Technology Acceptance Model (TAM) for Evaluating Acceptance Pega Application at PT. Sinar Mas Insurance Policy Services Division
}

Technology Acceptance Model (TAM) untuk Mengevaluasi Penerimaan Aplikasi Pega di PT. Asuransi Sinar Mas Divisi Polis Servis

Received:

10 October 2020

Accepted:

28 December 2020

Published:

1 February 2021

\author{
${ }^{1}$ Geofiton A. Dessilomba, ${ }^{2 *}$ Andeka Rocky Tanaamah \\ ${ }^{1,2}$ Department of Information and Technology, Universitas Kristen Satya \\ Wacana, Indonesia \\ ${ }^{1,2}$ Salatiga, Indonesia \\ E-mail:1'geofiton04@gmail.com, 2atanaamah@uksw.edu \\ *Corresponding Author
}

\begin{abstract}
This study describes and predicts how users accept the implemented technology. This research uses a qualitative method approach. Data collection was carried out by interviewing three employees of the Policy Services Division of PT Asuransi Sinar Mas. Researchers researched in March 2020. The data obtained were then processed through data reduction, data presentation, and description conclusions. The results showed that employees in the company could accept technology because they perceive ease of use and usability. The emergence of a positive attitude towards the use of technology impacts the high interest in technology use behavior to increase the actual use of technology. The positive attitude of users towards technology is indicated by the satisfaction of using technology from employees. Researchers can measure technology acceptance based on perceived ease of use, perceived usefulness, attitudes of using technology, interest in behavior using technology, and actual behavior using technology. It is necessary to improve the actual conduct of employees using technology that can improve company performance.
\end{abstract}

Keyword-Perceived Ease to Use, Perceived Usefulness, Technology Acceptance

\begin{abstract}
Abstrak-Penelitian ini menjelaskan dan memprediksi bagaimana pengguna menerima teknologi yang diimplementasikan. Penelitian ini menggunakan pendekatan metode kualitatif. Pengumpulan data dilakukan dengan cara wawancara kepada tiga karyawan Divisi Layanan Kebijakan PT Asuransi Sinar Mas. Penelitian dilaksanakan pada bulan Maret 2020. Data yang diperoleh kemudian diolah melalui reduksi data, penyajian data, dan penarikan kesimpulan. Hasil penelitian menunjukkan bahwa karyawan di perusahaan dapat menerima teknologi karena memiliki persepsi kemudahan penggunaan dan kegunaan. Timbulnya sikap yang positif terhadap penggunaan teknologi memiliki dampak pada tingginya minat terhadap perilaku penggunaan teknologi sehingga berdampak pada peningkatan penggunaan teknologi yang sebenarnya. Sikap positif dari pengguna terhadap teknologi ditunjukkan dengan kepuasan penggunaan teknologi dari para karyawan. Penerimaan teknologi dapat diukur berdasarkan persepsi kemudahan penggunaan, persepsi kegunaan, sikap penggunaan teknologi, minat dalam perilaku menggunakan teknologi, dan perilaku aktual menggunakan teknologi. Perlu dilakukan perbaikan perilaku aktual menggunakan teknologi pada karyawan yang dapat meningkatkan kinerja perusahaan.
\end{abstract}

Kata Kunci-Penerimaan Teknologi, Persepsi Kebermanfaatan, Persepsi Kemudahan 


\section{INTRODUCTION}

In the modern era like nowadays, science and technology are currently experiencing rapid development. Several kinds of research have been done in science to develop and advance the quality of life. Meanwhile, technology has been built and designed to facilitate several needs of modern society. In this sense, global technology improvements have influenced various aspects of life in politics, art, culture, and economics. The companies of different products or services take benefit of this technology development. They can be companies of telecommunication, service providers, and even related to government policy.

With this, the development of technology and science is becoming an essential aspect of social development. Although science and technology have an important influence in the framework of economic and social development, scientific innovation's capacity cannot, however, be broadly divided [1]. This can happen because not everyone can understand and master technology, especially in advancing its development. The process of technological change, such as adaptation, implementation, innovation, and technology transfer, are the leading and vital things of consequence. These technical change processes are essential for many companies in building their inventions.

Furthermore, companies can also use technological development to compete with similar companies by following this technological improvement. Hence, in this era, people can see that innovation has been a mandatory and adjustable keyword for business success [2]. Every design that has been created is to provide positive benefits and create various easiness and solutions for human activities [3].

Even though the innovation process is a complex and interactive process that is essentially systemic, the use of technology in the company is expected to ease employee performance so that employee performance improves. In this context, the users of technology must operate the technology to improve their operating performance. Knowing what the needs are and how the acceptance of employees is the initial stage of any business. The company can use this understanding and beneficial to the company for future development [4]. This acceptance can be defined as opposition from rejection, which can be interpreted as a favorable decision to use innovation. Companies in making decisions need to know the problems that affect users' decisions to use specific systems considered by companies during the development phase. Understanding user perceptions regarding the use of new technologies can help facilitate the further development of implementing a particular technology. Without the ability to accept and operate the company's latest technology, the technology has no value. It brings no benefit at all for the employees as well as the company. Thus, the acceptance of technology users is 
INTENSIF, Vol.5 No.1 February 2021

ISSN: 2580-409X (Print) / 2549-6824 (Online)

DOI: https://doi.org/10.29407/intensif.v5i1.14961

significant. It shows that the technology can be easily understood and operated by users or individual companies' employees.

According to previous studies, various theories and models are developed to describe and analyze user acceptance. Each model determines different factors to explain the acceptance of technology users. One of the models that can explain technology users' approval is the Theory of Reasoned Action (TRA). This theory is a cognitive theory that offers a conceptual-based framework for understanding how human behavior is in specific contexts. It is the basis of the Technology Acceptance Model (TAM), which explains more about internet acceptance with exact dimensions that can easily affect internet users. Until now, TAM has become one of the most sought-after research models and is used to predict how the level of use and recognition of information systems and technology by individual users [5], [6]. This model places each user behavior's trust factor with two variables: usefulness and ease of use [7]. This model provides an empirical description of a computer user's behavior aspects, where many users can efficiently operate the internet because it fits what they want [8].

Nowadays, technology is also needed by PT. Asuransi Sinarmas. As part of the business process, user acceptance is also an essential factor for the development of PT. Asuransi Sinarmas. Because of PT. Asuransi Sinarmas, a company engaged in insurance service [9], one of Indonesia's largest general insurance companies, also uses technology to help run the business processes. Sinarmas Insurance uses Pega system technology to help business processes in the company to support such a large business. Pega system is the software leader for digital transformation that develops software for customer relationship management and business process management [10]. Currently, Sinarmas Insurance focuses on the Pega systems software to help run its business processes. Thus, Sinarmas Insurance is all transferred to Pega.

Pega systems have a platform called the Pega platform. Sinarmas Insurance uses the Pega system software to support the company, especially in business process management, in policy input. The policy is an agreement between the insurer and the customer-the Pega system in PT. Asuransi Sinarmas is used in the data input and database storage. After using the Pega system, the data input process becomes faster than the web as the Pega system is a new technology that has just been applied at PT. Asuransi Sinarmas, the evaluation of user acceptance of this system needs to be done. This evaluation is to improve the effectiveness of technology used to increase company performance. Thus, by studying PT. Asuransi Sinarmas employees' acceptance of the Pega using the model TAM. Some parties can argue the research problem to know the extent of the Pega systems application's benefit in the TAM. Thus, this study aims to determine the usefulness and acceptability of the Pega systems application based on the TAM. 


\section{RESEARCH METHOD}

This research is descriptive qualitative research. This method is used to describe a phenomenon from a case and how it is characterized by using observation and surveys to collect data [11]. Data obtained through interviews. The research was conducted at PT Asuransi Sinar Mas, Policy Services Division, in March 2020 using three informants. They are the coordinator of marine policy insurance, expedition coordinator, printing coordinator, administration and service policy examiner, and head of the service regulation department. The data analysis process is carried out by reducing data, presenting data, and in the end, is to conclude. This study involves system users internally, namely application operators and consumers, as users of the system's insurance policy.

The initial research model used was the TAM model. The indicators used in the TAM model include External Variables, Perceptions of Usability, Perceptions of Ease of Use, Attitudes towards Application, Behavior of Desire to Use, and Actual Use. The indicators used in this model are Perception of Usability (PU) and Perception of Ease of Use (PEOU), which are the two main factors that influence the attitude of application users (Attitudes towards Application). The external variables used, namely: PU and PEOU act as a mediator of the relationship between external variables and user attitudes (Attitudes towards Application). This study uses two external variables (changes in the environment and encouragement from users) tailored to the research field, where these two external variables affect PU and PEOU.

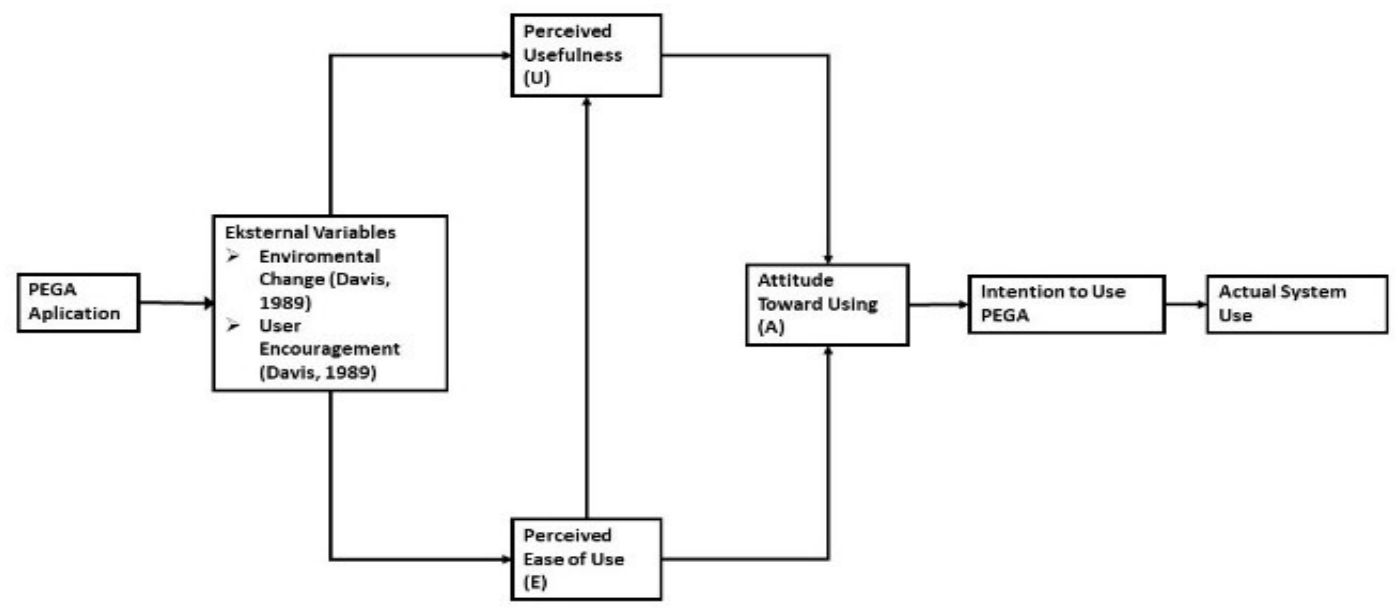

Figure 1. INITIAL MODEL

From the figure above, it can be seen that thing to do is to install the PEGA Application. After that, the researcher looks at the external variables: environmental change and user encouragement to get interview guidance towards the PT sample. Asuransi Sinarmas employees 
INTENSIF, Vol.5 No.1 February 2021

ISSN: 2580-409X (Print) / 2549-6824 (Online)

DOI: https://doi.org/10.29407/intensif.v5i1.14961

that have been chosen before. Based on this, it can be seen how People can perceive usefulness and ease of use. Thus, the Attitude Toward Using can be found through technology users, whether they have the intention to use the PEGA or not. After describing the conclusion from this step, Researchers can decide the use of the existing system.

\section{RESULT AND DISCUSSION}

This research is conducted to measure technology acceptance by its users, especially in Pega systems technology at PT. Asuransi Sinarmas, Policy Services Division. The model in this study was based on the Technology Acceptance Model (TAM). The technology acceptance model (TAM) introduces technology acceptance through measurement and interpretation of perceived ease of use, perceived usefulness, and interest in use as the primary constructs affecting technology acceptance.

TAM's primary constructs can determine how individual acceptance of implemented information technology is perceived ease of use and perceived usefulness. However, according to Davis, five forms influence a person's behavior towards information technology, namely perceived ease of use, perceived usefulness, attitudes towards application, the behavior of desire to use, and actual use of the system [12]. Therefore, Taking measurements can explain user acceptance of the technology. Users can also use it to find out perceptions of ease of use, perceived usefulness, attitudes towards application, the behavior of desire to use, and actual system usage. The results of interviews and discussions related to perceived ease of use, perceived usefulness, attitudes towards application, the behavior of the desire to use, and actual use of the system using the Pega system at PT Asuransi Sinar Mas, Policy Service Division are described as follows.

\section{A. Perceived ease of use}

Perceived ease of use describes the user's view of the comfort in operating and using the technology. Based on the perceived ease of Pega systems at PT. Asuransi Sinarmas Policy Services Division, in general, the document that is used by the company are per the document standards used in public. In this case, the management has made sufficient efforts to build a document control system that complies with the internal control system. The documents used have a simple, concise, and precise format and easy to understand by users not to experience difficulties in the filling process. It is to prevent filling errors by users, especially the insurance policy division. All used documents have their registration number so that The process can appropriately control copies' security in circulation. Besides, access to external storage media needs to be limited. Because access to external storage media is biased, data security is also more 
secured. Users perceive Pega systems as a technology that is not difficult to get operated by them. It is even accessible for users to apply. Pega systems have great information units, simple documents, and easy filling to input policy more quickly to make work done faster. Perceived ease of use is affected by user characteristics. Technology users and non-technology users have expressed computer anxiety, causing fear of new technology or even fear of using the latest technology, making it difficult for users to accept technology [13].

These workers have long experience working in fields using the computers in their work, so they were accustomed to the technology computer has offered and already know how to use computers to not have anxiety in using it. The absence of fear and self-efficacy in using computers can support users in perceived ease of technology use, that the new technology is considered easy to use and operate. Thus, according to this fact, technology users are quite confident in their ability to use the company's new technology. Some studies reported that other external factors could affect the perceived ease of use of technology other than self-efficacy of using computers and anxiety in using computers, namely training in technology use. It will apply technology use training and make users perceive that this technology can be operated and utilized efficiently [14], [15].

The use of Pega systems has been socialized before to the workers. Besides, the company has also conducted training on using Pega systems for workers who will use the technology. Workers understand well about the use of Pega systems and their operations. Thus, they have a good perception of the ease of use towards Pega systems, which can be a factor that can affect user acceptance of the technology. TAM construction in the form of perceived ease of use can predict sustainable use of technology applications that can describe technology acceptance [16]. Perceived ease of use can determine perceived usefulness. Easy to use technology and simple technology are considered to be more useful. Technologies that are continually being redesigned to improve usability and improve the user experience may be regarded as more valuable by users. It means that the perception of use can also affect the perception of usefulness [17].

\section{B. Perceived usefulness}

The perceived usefulness in question is the user's view of the benefit of technology. The research results related to perceived use showed that insurance policy products are always developing, so companies must keep up with technological development. Every time there is a new product, the company will create a system or modify the old system to support what is sold in the new product. Besides, the longer the company's products are, the more technology is needed to support the company's performance. Pega systems are applying technology in companies to help increasingly innovative products from the Sinar Mas insurance company. The company also realizes the importance of speed and accuracy of the information for company 
INTENSIF, Vol.5 No.1 February 2021

ISSN: 2580-409X (Print) / 2549-6824 (Online)

DOI: https://doi.org/10.29407/intensif.v5i1.14961

development. One of the fields that determine the accuracy and speed of presenting information the most has a fast and efficient information system. Therefore, the use of computers and the right program is vital for the company.

The results of this study indicated that Pega systems are perceived to provide benefit to the company. Workers believe that this technology can be beneficial for users, such as accelerating user performance and increasing user performance. Pega systems have a comprehensive approach so that all data processing can be done through Pega systems. It means that Pega systems data processing can support many data and make it easier to work. Thus, workers have a good impression of usefulness in using Pega systems. The excellent perception of Pega systems users can describe the acceptance of Pega systems by workers. Bildad and Hegner stated that two TAM constructs in perceived ease of use and perceived usefulness could predict technology applications' sustainable usage. Technology users who have an excellent feeling of ease of use and effectiveness can improve the user's intention to use technology. Perceived usefulness in technology adoption is more substantial than perceived ease in affecting interest in using technology [18].

C. The attitude of using technology

The attitudes of workers currently using Pega systems technology show both positive and negative attitudes in using the technology. One of the attitudes that can be observed regarding the use of technology is technology's satisfaction. The results showed that the workers are not satisfied enough with using Pega systems technology. Pega systems that were used today in general for the user interface was excellent and straightforward. It has to utilize a system by cross-checking to report the satisfaction so that workers do not need to do manual checks, which demands much time.

All Pega systems users in the service policy also make reports independently/manually to be used as a reference if they want to retrieve data quickly because data retrieval in the system has limitations. Workers were not entirely satisfied in terms of Pega systems features that were still far from perfect, where the speed of the system in inputting data has not kept up with the user's data input. Pega systems data input can support many data, but it was still not optimal for control and monitoring. Worker satisfaction with Pega systems was only about 50\%. System dissatisfaction also occurred because there were still many errors in the system, and errors occurred up to 1-2 days and must be reminded to the information technology section. Another obstacle to using Pega systems is that there were still many bugs in the design and the speed that always cannot keep up with user speed. Although workers were not entirely satisfied with Pega systems technology, users tend to have a positive attitude. It is due to the high perceived ease of use of technology and the perceived usefulness. 
Davis stated that the simplicity of technology usage procedures benefits the users, resulting in users' trust-achievements in using the technology (AttitudeTowards Using). The previous studies showed that ease of using new technology makes users want to adopt the technology (Attitude Towards Using). Simultaneously, the difficulties experienced by the users in utilizing the technology may contribute to new technology rejection. The previous studies about the benefits of technology also revealed that a technology that supports its users' performance would be trusted (Attitude TowardsUsing) [19]. According to Davis's research, attitudes towards application state that TAM conceptualizes attitudes towards the use of technology as attitudes towards using a system, namely in the form of user acceptance or rejection as an impact when someone uses information technology in his workbook. The philosophy of someone's approval or rejection of information technology depends on how high the level of trust is. For example, if someone has a high level of confidence in information technology. In this case, the user will show a positive attitude in accepting technology, namely the perspective in using technology, which is expressed as the user's attitude, which is demonstrated by their belief in the technology used. The attitude constructs in using technology represent the user's point of view on the use of technology. Thus, object-based attitudes to the use of technology are external variables that affected technology users' beliefs. Technology users' opinions have affected attitudes to use technology and interest in using technology [20]. Besides, the perspective of using technology is also stated to influence the intention to use technology. User attitudes towards technology affected interest through the user's belief in technology acceptance. When users find information systems that are fun and easy to use, they will have a positive attitude towards technology using. Thus, the attitude of using technology affected the level of technology acceptance. Users who are more satisfied with technological performance have a more vital perception of technology systems that are useful and easy to use.

\section{Interest in using}

Interest in using is how often users use this technology and how much they want to use it and invite other people to use it. In this study, the interest in using technology is the level of interest shown by workers in technology use and in encouraging others to use Pega systems technology. The results related to using Pega systems showed that workers use Pega systems according to their needs. Workers handle thousands of policies that are issued every month so that they require control and monitoring. So, a user-friendly information system that needed comprehensively can manage data to obtain valid data. The company's current system still has several weaknesses.

The behavior of the user's desire to use technology is shown as an action or reaction of an object or living being. Such behavior can occur whether consciously or unconsciously, honest or 
INTENSIF, Vol.5 No.1 February 2021

ISSN: 2580-409X (Print) / 2549-6824 (Online)

DOI: https://doi.org/10.29407/intensif.v5i1.14961

dishonest, voluntary or involuntary. Human behavior can be general or uncommon, acceptable, or unacceptable. Humans evaluate behavior by using comparative standards called social norms and regulating behavior using social controls. The action of the desire to use is the tendency of user behavior to keep using technology. Through this condition, it can be seen that the desire of users to continue using technology or to start using technology is influenced by the perception of ease of use and the perception of usability. When users quickly find the function they need, it considers the technology easy to use, improving the system's usability. When users have a positive perception of the usability and ease of technology use, users can achieve high efficiency and have a high intention to use the system.

\section{E. Actual use}

The actual use of the success or failure of a recently launched technology-based service in improving the service depends on the number of service users. An established technology will be successful if the number of users increases and is continuously used. Therefore, the use of technology by workers is an essential factor for companies. According to Rangkuti, the behavior is an action shown by someone to buy, spend, or use a product or service expected to meet their needs. Conduct that can meet someone's needs can relieve tension and pressure because It can meet requirements. The company has actualized the use of Pega systems, but the policy's intensity needs to be inputted. The policy input process through Pega systems is the first marketing to appeal to the underwriting department. After it is approved by the underwriting to be covered, marketing orders the quotation to the input operator in the service policy division to input data into the system. The checker will then recheck the data to make sure the data is correct according to the standard or not. If the information is correct, it will be transferred again to the underwriting department to be rechecked. After it is accurate and approved, it is sent to the printing department, followed by the expedition's insured.

There are two types of reporting: using the system and manual, but for reporting that uses the system to retrieve the data, it is a bit long. The service policy section itself makes manual reporting in excel to provide faster data. So for reporting, it has one display in the Pega systems application.TRA is specifically designed for modeling the user acceptance of information systems. The theory can explain the determinants of the acceptance of computer use in general, explaining user behavior for all ranges and populations of computer technology users, who meet in a penurious and theoretical manner. TAM proposes two things believed to be facts, perceived usefulness and ease of use, as the primary connection to computer acceptance behavior. Perceived ease describes the extent to which a person believes that using a particular system can improve their performance, and perceived ease of use is defined as the extent to which a person believes that using the system does not require any effort (free of action). Perceived ease of use 
also affected perceived usefulness, which can mean that if a person feels the system is easy to use, it is useful for him/her.

This study showed that workers in the company accepted the use of technology for they perceived the ease of use and usefulness, which resulted in a positive attitude towards the use of technology which affected the high interest in behavior using technology so that it has an impact on increasing the actual use of technology. This study's results were in line with Adnyasuari and Darma's research that the TAM theory's construct positively affected [21]. Perceived ease of use and perceived usefulness positively and significantly affect attitudes toward the service, and attitude satisfaction towards use had a positive and significant effect on actual system use. The company improves employees' ability, mostly employees of technology users, by providing explanations about new technology related to how to use, existing features and benefits for the company, and adding elements from technology to make workers feel easy, comfortable, and safe at work [22].

The company must organize the information and data presented based on workers' needs, allowing users to find data and process data quickly. A higher degree of perceived compatibility is associated with an increased intention to adopt the technology. It implies that people will be more willing to implement technology services if these services are by how they speed up work completion and make it easier to use technology to make it easier to complete work. Technology readiness is also stated to influence workers' perception of using technology and technology adoption. Behavioral interest in using technology is, in turn, determined simultaneously by attitudes toward behavior, subjective norm, and perceived behavioral control. Providing a higher quality of service is established as a prerequisite for success and survival in the online environment. This success is said directly, depending on user satisfaction and, indirectly, the service's quality of service. If managed efficiently, technology adoption can help address barriers to work, provide accurate and timely information, improve job performance, and multiply the quality of service and user satisfaction. User satisfaction is the essence of successful technology adoption. Hence, information technology can help in improving service quality for user satisfaction. Udo et al. showed that worker services' quality is an antecedent of worker satisfaction with technology. Job satisfaction has many benefits for economic entities. The user experience of technology applications is the main criterion for evaluating technology user satisfaction with technology.

The result implies that users will easily accept systems or software that they think is easy to use and benefit their work. The implication for policymakers in information systems and programmers is that in designing software, user perceptions are used to determine the software's format to be developed. Thus, if user perception or opinion is considered in determining the 
INTENSIF, Vol.5 No.1 February 2021

ISSN: 2580-409X (Print) / 2549-6824 (Online)

DOI: https://doi.org/10.29407/intensif.v5i1.14961

software structure, it is hoped that the resulting software can be more easily applied and executed by the user. The researchers found several external factors were by the TAM mapping from the interview results in the field. However, Researchers did not find several factors in the external variables that were mentioned by TAM. Thus, the addition of this new external factor is constructed in the final model, as shown in Figure 2, and will be explained in the next paragraph.

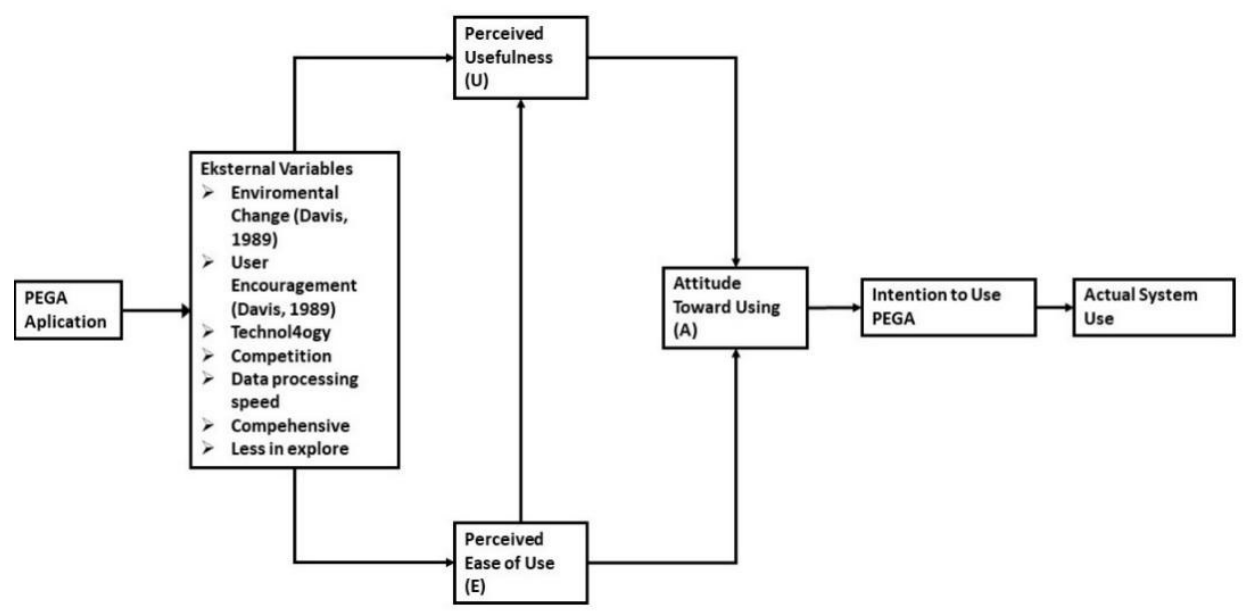

Figure 2. FINAL MODEL

From the Final Model Figure above, it can be seen that there are some changes found compared to the first figure that is used to conduct the research procedure. It can be seen that in the box of external variables, there are some additional variables. They are the technology, competition, data processing speed, comprehensive, and lack of exploration. Meanwhile, the rest of the figure plot is similar to the previous procedure figure found in the method section. However, in the final model, the external variables can directly move forward to use. It is continued to the intention of use (PEGA) and the actual system use. The external variables can pass through the perceived usefulness and perceived ease of use. The elaboration of additional external variables mentioned by TAM and found by researchers in the field is stated below:

\section{Technology}

In the field, the researcher found that this company needed the support of current technology. The problem is that the system used previously was very slow in processing customer data. The service policy department itself must be fast in processing customer data so that policy issuance does not take long, and customers can quickly get the policy. The regulation department handles many policy issuances that require users to work soon. However, problems in a slow system in processing data are serious obstacles that can affect customer satisfaction, where in the world of customer satisfaction, insurance is essential. There is a need for the latest technology, such as 
artificial intelligence or big data, to find out what consumers need so that companies can provide the right service.

\section{Competition}

In this study, the researcher found very tight competition between insurance companies to ensure customer satisfaction is paramount. Customer satisfaction is through improved service, one of which is making policy, so customers do not necessarily wait for too long to get a policy. With the system used before, it was still not able to help in issuing policy quickly. Applying a new design with the use of the latest technology, such as artificial intelligence or big data, can be a competitive advantage for companies to compete with competitors.

\section{Data processing speed}

Because all departments use this Pega, it causes the application speed in processing data was still lack. Also, this application was still often down and caused the user not to carry out policy input where the input must be completed on that day, with this problem delays the policy input. Therefore, there needs to be support for information systems that use artificial intelligence or big data so that data processing can be faster to support decision making.

\section{Comprehensive}

After conducting the interview, the researcher found that the Pega application was comprehensive in the data processing. It can support many things such as data reports inputted by the user, display a preview of the policy before printing, and the Pega application speed was faster than the previous application. The latest technology support to be implemented in all application functions can help companies make policy regarding consumers as a whole or comprehensively.

\section{Less in explore}

Even though Pega has already comprehensive, it can support many things in policy work and reporting in this application. However, it was still less explored in terms of controlling and monitoring. It should explore this problem more to make it easier in terms of monitoring and controlling. The form of control for the Pega application can be in the form of control systems and technology. System control by implementing an information system audit function to monitor the operational process of using the application. Meanwhile, technology control can use supporting hardware such as server security or other supporting hardware. 
INTENSIF, Vol.5 No.1 February 2021

ISSN: 2580-409X (Print) / 2549-6824 (Online)

DOI: https://doi.org/10.29407/intensif.v5i1.14961

\section{CONCLUSION}

The technology used by the company has a document that is simple and easy to fill in and has a compatible and straightforward, and comprehensive feature that allows workers to use this technology to process data together in one system. This condition impacts workers' perception of where workers have well-perceived ease of use of technology and usefulness. The company workers accepted the use of technology as they deemed the ease of use and benefit as good in a positive attitude towards technology use. It affected the high interest in behavior using technology so that it has an impact on improving the actual use of technology. The positive attitude toward the use of technology is reflected by the satisfaction of workers' technology use. All programs used in this technology have passwords and access rights according to each worker's duties and responsibilities. Workers are fully responsible for their respective passwords. The results of this study have implications that TAM acceptance's success depends on user perception. If users find the Pega system easy to use and useful, they will more readily accept TAM in their work. For decision-makers regarding the use of information systems in government institutions, with the results of this study, it is recommended to carry out trials and training on users before the procedure is officially implemented as a necessity. With structured tests and training, users will find it

\section{REFERENCES}

[1] M. Mormina, "Science, Technology, and Innovation as Social Goods for Development: Rethinking Research Capacity Building from Sen's Capabilities Approach," Sci Eng Ethics, vol. 25, no. 15, pp. 671-692, 2019.

[2] O. G. Ciobanu and D. M. Neamtu, "The impact and importance of new technologies in business development in the context of economic diversity," Proc. Int. Conf. Bus. Excell., vol. 11, no. 1, 2017.

[3] D. Kurniawati, "Pemanfaatan Teknologi Informasi dan Komunikasi Oleh Perangkat DesaGandulan Kecamatan Kaloran Kabupaten Temanggung," Yogyakarta State University, 2017.

[4] H. Taherdoost, "A review of technology acceptance and adoption models and theories," Procedia Manuf., vol. 22, 2018.

[5] H. Nadri, B. Rahimi, A. H. Lotfnezhad, M. Samadbeik, and A. Garavand, "Factors Affecting Acceptance of Hospital Information Systems Based on Extended Technology Acceptance Model: A Case Study in Three Paraclinical Departments," Appl Clin Inf., vol. 9, no. 2, pp. 238-247, 2018.

[6] H. Chen, W. Rong, X. Ma, Y. Qu, and Z. Xiong, “An Extended Technology Acceptance Model for Mobile Social Gaming Service Popularity Analysis,” Mob. Inf. Syst., vol. 2017, 2017.

[7] E. B. Diop, S. Zhao, and T. V. Duy, "An extension of the technology acceptance model for understanding travelers' adoption of variable message signs," PLoS One, 2019.

[8] H. Taherdoost, "Importance of Technology Acceptance Assessment for Successful Implementation and Development of New Technologies," Glob. J. Eng. Sci., vol. 1, no. 
3, 2019.

[9] R. Palpialy and R. Tanone, "Perancangan Alternatif Penawaran Plan Small Medium Enterprise Menggunakan Pegasystems 7 (Studi Kasus : PT. Asuransi Sinarmas)," J. Tek. Inform. dan Sist. Inf., vol. 4, no. 2, pp. 224-241, 2018.

[10] P. Lohchab, M. A. K. Sharma, and D. Y. Singh, "Pega System as a Business Process Management Tool,” Int. J. Eng. Res. Technol. ICADEMS, vol. 5, no. 3, 2017.

[11] C. Bradshaw, S. Atkinson, and O. Doody, "Employing a Qualitative Description Approach in Health Care Research," Glob. Qual. Nurs. Res., 2017.

[12] G. A. Haris and E. Mardiati, "The Influence Of Technology Acceptance Model (TAM) Towards Customer Satisfaction Of Zahir Accounting Application,” Int. J. Humanit. Relig. Soc. Sci., vol. 3, no. 9, 2019.

[13] J. D. Portz and E. Al., "Using the Technology Acceptance Model to Explore User Experience, Intent to Use, and Use Behavior of a Patient Portal Among Older Adults With Multiple Chronic Conditions: Descriptive Qualitative Study," JMIR Publ., vol. 21, no. $4,2019$.

[14] N. Gordon and M. C. Hornbrook, "Differences in access to and preferences for using patient portals and other eHealth technologies based on race, ethnicity, and age: a database and survey study of seniors in a large health plan," J Med Internet Res, vol. 18, no. 3, 2016.

[15] C. J. Sieck and E. Al., "The rules of engagement: perspectives on secure messaging from experienced ambulatory patient portal users," JMIR Med Inf., vol. 5, no. 3, 2017.

[16] A. D. Beldad and S. M. Hegner, "Expanding the Technology Acceptance Model with the Inclusion of Trust, Social Influence, and Health Valuation to Determine the Predictors of German Users' Willingness to Continue using a Fitness App: A Structural Equation Modeling Approach,” Int. J. Human-Computer Interact., vol. 34, no. 9, pp. 882-893, 2018.

[17] D. Z. Dumpit and C. J. Fernandez, "Analysis of the use of social media in Higher Education Institutions (HEIs) using the Technology Acceptance Model," Int. J. Educ. Technol. High. Educ., vol. 14, no. 5, 2017.

[18] J. Cho, "The impact of post-adoption beliefs on the continued use of health apps," Int. J. Med. Inform., vol. 87, pp. 75-83, 2016.

[19] A. Dhea and A. R. Tanaamah, "Technology acceptance model for evaluating IT of online-based transportation acceptance: a case of GO-JEK in Salatiga," TELKOMNIKA vol. 17, no. 2, 2019.

[20] K. F. Ho and E. Al., "Theoretical integration of user satisfaction and technology acceptance of the nursing process information system," PLoS One, vol. 14, no. 6, 2019.

[21] P. A. S. Adnyasuari and G. S. Darma, "Technology Acceptance Model and ESatisfaction in Mobile Banking," J. Manaj. dan Bisnis, vol. 14, no. 2, 2017.

[22] J. S. Suroso and E. Al., "Evaluation of Knowledge Management System Using Technology Acceptance Model," in Proc. EECSI 201719 -21 September, Yogyakarta, Indonesia, 2017. 